\title{
Coalition pursues ban on animals in teaching
}

Munich. The local government of Hessen, one of Germany's 16 Länder, has confirmed its commitment to eliminating the use of animals from undergraduate teaching at its universities. Two weeks ago, it told a professor of zoology at the University of Marburg, Gerald Heldmaier, to stop using animals in his courses.

The move has come despite a ruling by an administrative court last December that the country's animal protection laws could not be used to restrict the freedom of university teachers, which is protected by Germany's federal constitution, from outside interference (see Nature 367, 103; 1994).

Last year, Heldmaier, with the support of the University of Marburg, persuaded a local administrative tribunal to issue an injunction against an earlier attempt by the on the use of animals in teaching. This was subsequently upheld by the state administrative court.

The government, made up of a 'redgreen' coalition of Social Democrats and Greens, says that it has further evidence to ssupport its demand that Heldmaier should stop using animals in his course.

But the government itself appears to be split on the issue, as the state's ministry of science has at the same time told the University of Marburg that it can pay the costs of any legal action to defend Heldmaier out of its state funds.

Heldmaier, who intends to appeal against the government's new ruling, has vociferously defended his right to include a single animal experiment in his zoology under- graduate course. This involves a study of the intestinal absorption of glucose from the intestines of anaesthetized rats.

$\mathrm{He}$ argues that zoology students should have practical experience of the control of anaesthesia, as well as practical knowledge of simple surgical techniques. But opponents claim that the same information can be derived from showing students videotapes of the operation (see Nature 365, 778; 1993).

Heldmaier claims that, if the Hessen

government wins, it could set a precedent for the state government to interfere in other areas of university teaching. But the conflict has arisen from the fact that the use of animals in teaching is strictly limited by the German Animal Protection Act.

"This is a political principle, and a very tense question," says a spokesman for the state government. "If necessary we will defend our decision right up to the highest court, the federal constitutional court [in Karlsruhe]."

Alison Abbott

\section{Livermore head promises openness} Hessen government to impose a general ban

San Francisco. C. Bruce Tarter, appointed last director of the week as the new $L$ a $w r$ e $n$ c e Livermore National Laboratory in California, says that he plans to lead the science institution into an era of more openness

\section{IMAGE \\ UNAVAILABLE FOR COPYRIGHT REASONS} public and the technical community.

Tarter, who is 54, has been acting director since last May, when he succeeded John Nuckolls. An astrophysicist, Tarter has worked at the laboratory for 27 years. "I believe the Livermore Laboratory is the outstanding applied science instituand greater interaction with both the US

\section{Moscow meeting raises research fund hopes}

Washington. A joint US-Russian research foundation first proposed more than two years ago (see Nature 355, 576; 1992), may finally get off the ground at a meeting this week in Moscow between the US Vice President Al Gore and the Russian Prime Minister Viktor Chernomyrdin, according to White House officials.

The meeting will also attempt to solve problems with projects that the two countries have already set in motion. These include difficulties in getting scientific equipment through Russian bureaucracy and customs and in allowing scientists access to sensitive areas.

More than two years ago, at the instigation of Representative George Brown (Democrat, California), Congress approved the creation of a joint US-Russian research foundation, to be administered by the $\mathrm{Na}$ tional Science Foundation. So far, however, the money has failed to materialize.

The Department of Defense (DoD), which was to have paid some $\$ 10$ million into the so-called 'Brown Fund', has been reluctant to part with the money, and the White House has shown no willingness to force its hand. has not done this," complains one frustrated congressional staff member who worked to pass the legislation.

The DoD has previously claimed that the transfer of funds would be illegal. But Jeff Schweitzer of the White House Office of Science and Technology Policy says he hopes the legal questions can be settled in time for the meeting on 15 and 16 December.

The meeting between Gore and Chernomyrdin, part of a continuing series of talks on cooperation between the two countries, is also expected to initiate several new joint projects. These include a space biomedical centre in Moscow funded largely by the US National Aeronautics and Space Administration, biodiversity studies, research on nuclear waste processing, and a project to measure ocean temperature in cooperation with the Advanced Research Projects Agency.

Tony Reichhardt "I don't understand why the administration tion in the country, and it will be my job to ensure that its capabilities are applied to the nation's highest technical priorities," he told a news conference at the laboratory last week.

Tarter takes over the directorship of Lawrence Livermore at a time when the national laboratories face potential dismantling of their sponsor, the Department of Energy, as well as threats of severe budget cuts from the new Republican-dominated Congress. A report commissioned last year by Hazel $O$ 'Leary, the Energy Secretary, on the management of US weapons laboratories is due to be completed in February.

As a result of such pressures, Tarter is likely to be called upon to cut spending perhaps by redeploying staff - and to justify the laboratory's varied programmes. As acting director, Tarter has already encouraged closer collaboration with industry, and has declared a goal of making the laboratory more "user-friendly".

Tarter said last week that the ending of the Cold War meant that it was time for the laboratory to revise its mission. He emphasized its potential for carrying out important research and development work in energy, the environment, bioscience and health care.

One scientist familiar with the laboratory says that Tarter has already demonstrated as acting director an ability to convey the importance of the laboratories to the public, and that his commitment to openness and communication with employees is also paying off, for example by improving the dedication and productiveness of staff. Both public and staff support are likely to be critical in the laboratory learns to adapt to a changing environment.

Tarter was appointed by the University of California Board of Regents, which manages the laboratory for the Energy Department. He is the tenth director since the laboratory was founded as part of the US nuclear weapons programme in 1952.

Sally Lehrmann 